\title{
Incidence, predictors, and management of acute coronary occlusion after coronary angioplasty
}

\author{
Pim J. de Feyter, MD, Peter P. T. de Jaegere, MD, and Patrick W. Serruys, MD
}

Rotterdam, The Netherlands

\begin{abstract}
Despite increased operator experience and skill and improved technology of balloons and x-ray equipment, the incidence of abrupt occlusion has not decreased dramatically and is reported to be between $4.4 \%$ and $8.3 \%^{1-7}$ (Table I). The lack of decreased incidence of acute occlusion is the result of the proportional increase of patients who undergo dilation of complex lesions and of acute ischemic syndromes that are associated with a higher likelihood of acute occlusion. ${ }^{1,4,8}$ Abrupt coronary occlusion is a highly unwanted, often unpredictable event associated with major complications including death and myocardial infarction; it is the main reason for the requirement for immediate surgical back-up (Table I). This article reviews the incidence, predictors, and current management of abrupt coronary occlusion during coronary intervention.
\end{abstract}

\section{INCIDENCE AND PREDICTORS}

Morphologic causes of acute coronary occlusion. The mechanisms of abrupt coronary artery occlusion include a combination of mechanical obstruction caused by (sub)occlusive dissection, subintimal hemorrhage under the plaque, thrombus formation, vasoconstriction, and elastic recoil..$^{9-12}$ Invariably, recoil occurs after balloon angioplasty, accounting for approximately $40 \%$ to $50 \%$ of immediate lumen loss ${ }^{12}$ The establishment of the other causes of acute coronary occlusion is being hampered by the insensilivity of angiography to reliably identify the main mechanism

From Thoraxcenter, Iniversity Hospital Dijkzigt, Rotterdam. Received for publication June 18, 1993; accepted Aug. 16, 1993.

Reprint requests: P. J. de Feyter, MD, Catheterization Laboratory, Thoraxcenter Bd 432, University Hospital Dijkzigt, Erasmus University Rotterdam, P.O. Box 1738, 3000 DR Rotterdam, The Netherlands.

AM HEART J 1994;127:643-51.

Copyright is 1994 by Mosby-Year Book, Inc.

$0002-8703 / 94 / \$ 3.00+0 \quad \mathbf{4} / \mathbf{1} / \mathbf{5 1 9 5 2}$ of occlusion. Generally, one distinguishes between either thrombus or occlusive dissection, but often the mechanism is indeterminate. Thrombus formation was thought to be the predominant mechanism in $19 \%$ to $33 \%$ of patients, dissection in $26 \%$, and the combination in $7 \%$, whereas in $42 \%$ it was not possible to establish the underlying cause. ${ }^{5,6}$ These findings clearly reflect the inability of angiography to reliably detect intracoronary abnormalities. Newer intracoronary imaging techniques such as intracoronary ultrasound imaging and angioscopy may be useful in establishing the mechanisms and helpful in guiding optimal management.

Incidence of abrupt occlusion. Abrupt coronary occlusion was defined as clinical or electrocardiographic evidence of myocardial ischemia and a complete (Thrombolysis In Myocardial Infarction [TIMI grade 0]) or critical reduction (TIMI grades 1 or 2) in coronary blood flow of a previously patent (TIMI grades 2 or 3 ) coronary vessel segment occurring during or after coronary intervention within the period of hospitalization. Abrupt coronary occlusion of a previously totally occluded artery was defined as reclosure (TIMI grades 0 or 1) after establishment of TIMI grade 3 flow during initial successful intervention; this reclosure may be associated with ischemia. The reported incidence of abrupt coronary occlusion during and after coronary intervention ranges from $4.4 \%$ to $8.3 \%$, with an average of $5.7 \%{ }^{1-7}$ (Table I).

Predictors of abrupt coronary occlusion. For optimal clinical decision-making and patient counseling, it would be desirable if one could identify preprocedural and procedural high-risk procedures. Several predictors for acute coronary occlusion have been identified (Table II), but unfortunately they generally have a low positive or negative predictive value. ${ }^{3-5,8,13-16}$ However, the make-up of a risk profile for each patient is often helpful and allows a crude estimation of the potential risk, such that in case of 
Table I. Incidence and major complications associated with (sub)acute occlusion during balloon angioplasty

\begin{tabular}{|c|c|c|c|c|c|c|c|}
\hline & \multirow[b]{2}{*}{ Year } & \multirow[b]{2}{*}{$\begin{array}{l}\text { Study } \\
\text { period }\end{array}$} & \multirow[b]{2}{*}{$\begin{array}{c}\text { No. of } \\
\text { patients }\end{array}$} & \multirow{2}{*}{$\begin{array}{c}\text { Incidence of } \\
\text { (sub)acute } \\
\text { occlusion } \\
\text { No. }(\%)\end{array}$} & \multicolumn{3}{|c|}{ Major complications } \\
\hline & & & & & $\begin{array}{c}\text { Death } \\
\text { No. }(\%)\end{array}$ & $\begin{array}{c}A M I \\
\text { No. }(\%)\end{array}$ & $\begin{array}{c}\text { Emergency } C A B G \\
\text { No. (\%) }\end{array}$ \\
\hline \multicolumn{8}{|l|}{ Early experience } \\
\hline \multicolumn{8}{|l|}{ NHLBI-PTCA } \\
\hline Registry $\mathrm{I}^{1}$ & '83 & '77-'81 & 1,500 & $112(7.5)^{*}$ & $8(7.2)$ & $41(37)$ & $86(77)$ \\
\hline Beth Israel ${ }^{2}$ & '88 & '81-'86 & 1,160 & $54(4.7)$ & $1(1.9)$ & $19(35)$ & $18(33)$ \\
\hline Emory $^{3}$ & '88 & '82-'86 & 4,772 & $210(4.4)$ & $4(2.9)$ & $56(40) \dagger$ & $78(55)+$ \\
\hline \multicolumn{8}{|l|}{ Late experience } \\
\hline \multicolumn{8}{|l|}{ NHLBI-PTCA } \\
\hline Registry II ${ }^{4}$ & ’90 & '85-'86 & 1,801 & $122(6.8)$ & $6(4.9)$ & $49(40)$ & $49(40)$ \\
\hline Thorax Center $^{5}$ & '91 & '86-'88 & 1,423 & $104(7.3)$ & $6(6.0)$ & $37(36)$ & $30(31)$ \\
\hline Ann Arbor ${ }^{6}$ & '92 & '88-'90 & 1,319 & $109(8.3)$ & $9(8.3)$ & $22(20)$ & $25(23)$ \\
\hline $\begin{array}{l}\text { San Francisco } \\
\quad \text { Ileart Institute }\end{array}$ & '92 & '90-'91 & 553 & $27(4.9)$ & $0(0)$ & $9(33)$ & $11(41)$ \\
\hline Totals (average) & & & 11,028 & $626(5.7)$ & $26(4.7)$ & $192(35)$ & $211(38)$ \\
\hline
\end{tabular}

$A M I$, Acule myocardial infarction; $C A B G$, coronary artery bypass grafling; NHLBI, National Heart, Lung, and Blood Instilute; PTCA, perculaneous transluminal coronary angioplasty.

*Acute occlusion + major dissection causing complications.

+Subgroup analysis of 140 patients with suitable review angiograms.

Table II. Predictors of acute coronary occlusion

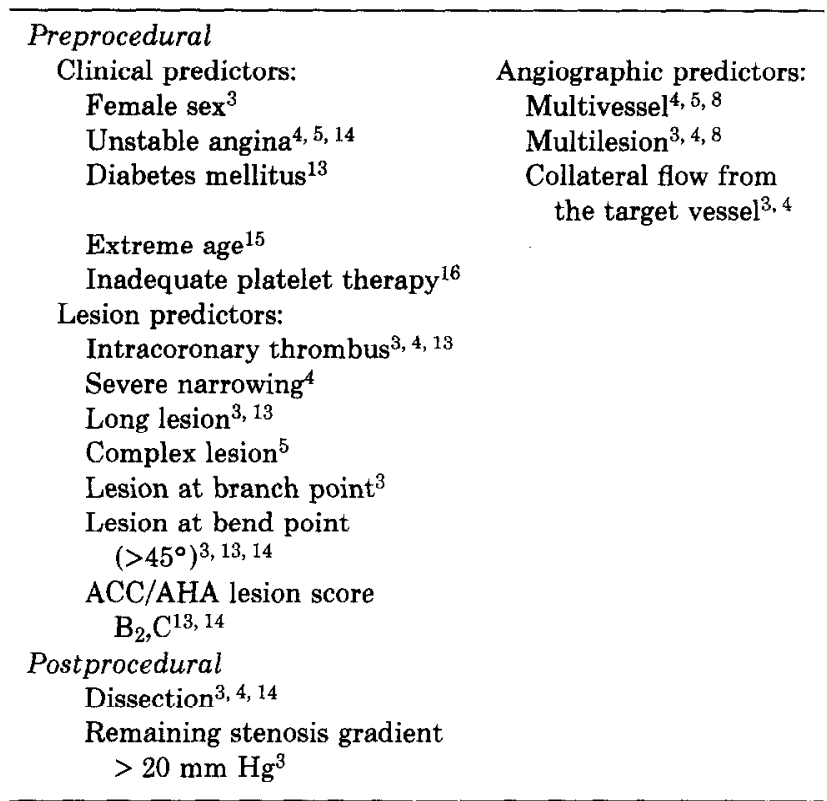

ACC, American College of Cardiology; AHA, American Heart Association.

the absence of any risk factor the probability of acute occlusion is very low $(2 \%)$, whereas the presence of one or more risk factors clearly increases the probability of acute coronary occlusion. In case of the presence of three risk factors, ${ }^{5}$ this may add up to a $25 \%$ probability. ${ }^{5}$

The recently proposed 1988 American College of Cardiology/American Heart Association (ACC/AHA) Task Force classification scheme that categorizes lesions into types $A, B$, and $C$ was developed to classify patients with high, medium, and low risk. Myler et al. ${ }^{7}$ report the short-term results in 553 consecutive patients classified according to this scheme. Angioplasty success was achieved in $99 \%$ of type A, in $92 \%$ of type $\mathrm{B}$, and in $90 \%$ of type $\mathrm{C}$ lesions. Untoward events occurred in $1.2 \%$ of type $\mathrm{A}$, in $1.9 \%$ of type $\mathrm{B}$, and in $2 \%$ of type $\mathrm{C}$ lesions. These results are clearly outside the range of the classification and seriously bring into question the value of the classification. An updated classification system needs to be developed that better fits the results obtained with current balloon technology.

Obviously, identification of risk factors predictive of procedural death is important. It appears that procedural death is closely related to the presence of a large amount of myocardium at risk, although the extent of preexisting nonviable myocardium should also be considered. Predictors of death are left main coronary artery disease, collaterals originating from the attempted dilated vessel, severely compromised left ventricular function, and female sex. . $^{817}$ Adequate prediction of the likelihood of acute occlusion has important consequences for the surgical standby. Patients with excessive risk for balloon angioplasty should be referred for elective bypass surgery. High-risk patients require active surgical standby, whereas medium and low-risk patients require only passive surgical standby.

\section{MANAGEMENT}

In-hospital outcome of acute coronary occlusion. In the very early experience of percutaneous transluminal coronary angioplasty ( $P^{\prime}$ TCA), acute coronary occlusion complicating PTCA was traditionally treated with an emergency coronary artery bypass 
Table III. Outcome after initial successful redilation of acute occlusion

\begin{tabular}{|c|c|c|c|c|c|}
\hline & \multirow[b]{2}{*}{$\begin{array}{l}\text { No. of patients with } \\
\text { attempted redilation }\end{array}$} & \multirow{2}{*}{$\begin{array}{c}\text { Successful } \\
\text { redilation } \\
\%(\text { No. })\end{array}$} & \multicolumn{3}{|c|}{$\begin{array}{l}\text { Major in-hospital complications } \\
\text { after successful redilation }\end{array}$} \\
\hline & & & $\begin{array}{l}\text { Death } \\
\%(\text { No. })\end{array}$ & $\begin{array}{c}M I \\
\%(N o .)\end{array}$ & $\begin{array}{c}\operatorname{Em} C A B G \\
\% \text { (No.) }\end{array}$ \\
\hline Beth Israel $^{2}$ & 43 & $51(22)$ & $0(0)$ & $14(3)$ & $0(0)$ \\
\hline NHLBI-PTCA II ${ }^{4}$ & 122 & $49(60)$ & $5(3)$ & $27(16)$ & $10(6)$ \\
\hline Thorax Center ${ }^{5}$ & 95 & $35(33)$ & $3(1)$ & $3(1)$ & $3(1)$ \\
\hline Totals (average) & 260 & $44(115)$ & $3.5(4)$ & $17(20)$ & $6(7)$ \\
\hline
\end{tabular}

Em, Emergency; $M I$, myocardial infarction; other abbreviations as in Table I.

Table IV. Outcome of treatment of abrupt occlusion with intracoronary or intravenous thrombolytics and redilatation

\begin{tabular}{|c|c|c|c|c|c|c|c|}
\hline \multirow[b]{2}{*}{ Study } & \multirow[b]{2}{*}{$\begin{array}{c}\text { No. of } \\
\text { patients }\end{array}$} & \multirow[b]{2}{*}{$\begin{array}{l}\text { Clinical } \\
\text { Success } \\
\text { No. }(\%)\end{array}$} & \multicolumn{3}{|c|}{$\begin{array}{l}\text { Failure with major } \\
\text { complications }\end{array}$} & \multirow[b]{2}{*}{$\begin{array}{l}\text { Failure without } \\
\text { major complications } \\
\text { (No.) }\end{array}$} & \multirow[b]{2}{*}{$\begin{array}{c}\text { Thrombolytic } \\
\text { treatment }\end{array}$} \\
\hline & & & $\begin{array}{c}\text { Death } \\
\text { (No.) }\end{array}$ & $\begin{array}{c}M I \\
(N o .)\end{array}$ & $\begin{array}{c}E m C A B G \\
\quad(N o .)\end{array}$ & & \\
\hline Gulba $^{20 *}$ & 27 & $13(48)$ & 0 & 14 & 2 & 0 & TPA \\
\hline Schieman $^{21} \dagger$ & 48 & $43(90)$ & 0 & 0 & 1 & 5 & Urokinase \\
\hline de Feyter ${ }^{5 *}$ & 34 & $18(53)$ & 2 & 13 & 5 & 0 & Streptokinase \\
\hline Verna $22 *$ & 23 & $15(65)$ & 1 & 5 & 3 & 0 & Urokinase \\
\hline Vaitkus $^{23} \uparrow$ & 27 & $14(52)$ & 0 & 8 & 4 & 0 & Urokinase \\
\hline Totals (average) & 159 & $103(65)$ & $3(1.9)$ & $40(25)$ & $15(9.5)$ & $5(3.2)$ & \\
\hline
\end{tabular}

TPA, Tissue plasminogen activator; other abbreviations as in Tables I and III.

*Abrupt occlusion during PTCA of patients with stable and unstable angina.

$\uparrow$ All patients had PTCA for acute ischemic syndromes.

operation. ${ }^{1}$ However, as experience accumulated, it became established practice, after first ruling out the possibility of acute occlusive coronary spasm with intracoronary nitroglycerin, to perform immediate redilation. ${ }^{18,19}$ Successful initial redilation can be achieved in an average of $44 \%$ of patients (Table III). Although the reopening is sustained in the majority of patients, in a few patients reocclusion with death, myocardial infarction, and the need for emergency surgery occurs (Table III). When initial redilation was unsuccessful and thrombus formation appeared, adjunctive thrombolytic treatment, in combination with repeated dilation, was given. The outcome of this combined approach is displayed in Table IV; the average success rate was $65 \% .{ }^{5,16-23}$ Failure of this combined treatment cannot totally be attributed to failure of thrombolytic therapy, but should also be ascribed to the difficulty in differentiating between dissection and thrombus using angiography. New intracoronary imaging techniques such as intracoronary angioscopy should be able to better distinguish between these mechanisms and should facilitate the management of these patients.

Emergency surgery after failed PTCA has been shown to be associated with a high mortality (aver-
Table V. In-hospital results of emergency bypass surgery after failed balloon angioplasty*

\begin{tabular}{lcccc}
\hline & $\begin{array}{c}\text { Total } \\
\text { group } \\
\text { No. }\end{array}$ & $\begin{array}{c}\text { Emergency } \\
\text { NoBG } \\
\text { No. }(\%)\end{array}$ & $\begin{array}{c}\text { Q wave } \\
\text { No. } \\
\text { No. } \%)\end{array}$ & $\begin{array}{c}\text { Mortality } \\
\text { No. (\%) }\end{array}$ \\
\hline Cowley $^{24}$ & 3,079 & $202(7)$ & $52(26)$ & $13(6.5)$ \\
Golding $^{25}$ & 1,831 & $81(4.5)$ & $37(46)$ & $2(2.5)$ \\
Killen $^{26}$ & 3,000 & $115(4)$ & $50(44)$ & $13(11)$ \\
Reul $^{27}$ & 518 & $70(13.5)$ & $8(11.4)$ & $4(5.7)$ \\
Talley $^{28}$ & 7,246 & $430(6.0)$ & $91(21)$ & $6(1.4)$ \\
Greene & & & \\
$\quad$ Totals (average) & 16,214 & $53(4.4)$ & $27(51)$ & $2(4.0)$ \\
& 1688 & $951(5.7)$ & $265(28)$ & $40(4.2)$ \\
\hline
\end{tabular}

Abbreviations as in Tables I and III.

*Selected were studies that included patients with more than 500 angioplasty procedures.

age $4.2 \%$ ), and the progression to a myocardial infarction can not be prevented in $28 \%$ of patients on average (Table V). ${ }^{24-29}$ The main feature that correlated best with perioperative death and myocardial infarction after acute surgery for complicated angioplasty appeared to be ongoing ischemia and hemodynamic instability. ${ }^{30}$ The overall outcome of the management of acute occlusion using either redilation or a combination of thrombolytics and, in case of 
Table VI. Overall management outcome of acute occlusion using a combination of redilation, thrombolysis, and emergency surgery

\begin{tabular}{|c|c|c|c|c|c|c|c|c|c|}
\hline & \multirow{3}{*}{$\begin{array}{l}\text { No. of } \\
\text { patients } \\
\text { with acute } \\
\text { occlusion }\end{array}$} & \multicolumn{4}{|c|}{ Management } & \multicolumn{4}{|c|}{ In-hospital outcome } \\
\hline & & \multirow[b]{2}{*}{$\begin{array}{c}\text { Conservative } \\
\text { No. }(\%)\end{array}$} & \multirow[b]{2}{*}{$\begin{array}{c}\text { Initial } \\
\text { re-PTCA } \\
\text { No. }(\%)\end{array}$} & \multirow[b]{2}{*}{$\begin{array}{c}\text { Thrombolytics } \\
\text { No. (\%) }\end{array}$} & \multirow[b]{2}{*}{$\begin{array}{c}E m C A B G \\
\text { No. }(\%)\end{array}$} & \multirow[b]{2}{*}{$\begin{array}{l}\text { Successt } \\
\text { No. (\%) }\end{array}$} & \multirow[b]{2}{*}{$\begin{array}{c}\text { Failure, } \\
\text { no complications } \\
\text { No. }(\%)\end{array}$} & \multicolumn{2}{|c|}{$\begin{array}{l}\text { Failure, with } \\
\text { complications }\end{array}$} \\
\hline & & & & & & & & $\begin{array}{c}M I \\
\text { No. }(\%)\end{array}$ & $\begin{array}{c}\text { Death } \\
\text { No. (\%) }\end{array}$ \\
\hline Beth Israel $^{2}$ & 54 & $14(26)$ & $40 \quad(74)$ & $0(0)$ & $18(33)$ & $31(57)$ & $8(15)$ & $19(35)$ & $1(2.0)$ \\
\hline NHLBI-PTCA II ${ }^{4}$ & 122 & $20(16)$ & $103(84)$ & $0(0)$ & $43(35)$ & $60(49)$ & $9(7)$ & $48(39)$ & $6(5.0)$ \\
\hline Thorax Center ${ }^{5}$ & 104 & $5(5)$ & $95 \quad(91)$ & $34(33)$ & $31(30)$ & $56(54)$ & $4(4)$ & $37(36)$ & $6(6.0)$ \\
\hline Ann Arbor 6 & 109 & $0(0)$ & $98 *(90)$ & $42(39)$ & $25(23)$ & $61(56)$ & $17(16)$ & $22(20)$ & $9(8.0)$ \\
\hline Totals (average) & 389 & $39(10)$ & $336 \quad(87)$ & $76(20)$ & $117(30)$ & $208(53)$ & $38(10)$ & $126(33)$ & $22(5.7)$ \\
\hline
\end{tabular}

Abbreviations as in Tables I and III.

*In 11 of 109 patients other techniques (stent nine; atherectomy nine) were employed.

†Success was defined as a successful reopened vessel or successful CABG without the occurrence of death or myocardial infarction.

Table VII. In-hospital events following stent implantation for threatened or acute occlusion after balloon angioplasty

\begin{tabular}{|c|c|c|c|c|c|c|c|c|c|}
\hline & \multirow[b]{2}{*}{ Year } & \multirow{2}{*}{$\begin{array}{l}\text { Study } \\
\text { period }\end{array}$} & \multirow{2}{*}{$\begin{array}{c}\text { No. of } \\
\text { patients }\end{array}$} & \multirow{2}{*}{$\begin{array}{c}\text { Successful } \\
\text { stent delivery }\end{array}$} & \multicolumn{3}{|c|}{ Complications } & \multicolumn{2}{|c|}{ Subsequent occlusion } \\
\hline & & & & & Death & $A M I$ & $E m C A B G$ & Incidence & Time interval \\
\hline \multicolumn{10}{|l|}{ Wallstent } \\
\hline Sigwart et al. ${ }^{35}$ & '88 & '86-'88 & 11 & $100 \%$ & $1(9 \%)$ & 0 & 0 & $1(9 \%)$ & NR \\
\hline de Feyter et al. ${ }^{36}$ & '90 & '89-'90 & 15 & $100 \%$ & $1(6.6 \%)$ & $2(13.3 \%)$ & $9(60 \%)^{*}$ & $3(20 \%)$ & Day $0-7$ \\
\hline Goy et $\mathrm{al}^{37}$ & '92 & NR & 17 & $100 \%$ & 0 & $1(5.8 \%)$ & 0 & $1(5.8 \%)$ & Day 0 \\
\hline \multicolumn{10}{|l|}{ Palmaz-Schatz stent } \\
\hline Haude et al. ${ }^{38}$ & '91 & NR & 15 & $100 \%$ & 0 & 0 & $1(6.7 \%)$ & $1(6.7 \%)$ & Day 0 \\
\hline Herrmann et al ${ }^{39_{\dagger}}$ & '92 & '88-'91 & 56 & $98 \%$ & $2(3.6 \%)$ & $11(20 \%)$ & $7(13 \%)$ & $9(16 \%)$ & Days1-10 \\
\hline Reifart et al. ${ }^{40}$ & '92 & '90-'91 & 64 & $95 \%$ & $4(6 \%)$ & $2(3 \%)$ & $7(11 \%)$ & $20(31 \%)$ & Days0-19 \\
\hline \multicolumn{10}{|c|}{ Gianturco-Roubin stent } \\
\hline Roubin et al. ${ }^{41}$ & '92 & '89-'91 & 115 & $96 \%$ & $2(1.7 \%)$ & $8(6.7 \%) \ddagger$ & $5(4.2 \%)$ & $9(7.6 \%)$ & Days $1-5$ \\
\hline \multicolumn{10}{|l|}{ Strecker stent } \\
\hline Reifart et al. ${ }^{40}$ & '92 & '90-'91 & 48 & $97 \%$ & $5(10 \%)$ & $1(2 \%)$ & $3(6 \%)$ & $10(21 \%)$ & Days0-19 \\
\hline \multicolumn{10}{|l|}{ Wiktor stent } \\
\hline Vrolix et al. ${ }^{42}$ & '92 & ’91 & 119 & $95 \%$ & $4(3 \%)$ & NR & $7(6 \%)$ & $14(12 \%)$ & NR \\
\hline Totals (average) & & & 460 & $97 \%$ & $19(4.1 \%)$ & $25(10.6 \%)$ & $39(8.4 \%)$ & $68(14.7 \%)$ & \\
\hline
\end{tabular}

NR, Not reported; other abbreviations as in Tables I and III.

*Includes the 8 patients in whom the stent was used as a bridge to surgery.

†Events within 30 days after stent implantation are reported.

$\ddagger$ If patients in whom the stent was implanted because of evolving AMI are excluded, value is $4 \%$.

failure, emergency surgery, is presented in Table VI. The incidence of death after acute occlusion was an average $5.7 \%$, and a myocardial infarction occurred in $33 \%$ of the patients. The average success rate was $53 \%$ (success being defined as an open vessel or successful bypass surgery without the occurrence of death or myocardial infarction).

Prolonged balloon inflations. Prolonged balloon inflations may improve the immediate result after PTCA because a long inflation time may improve remodeling of the atherosclerotic obstruction or may "tack-up" a coronary occlusive flap. It is important to note, however, that long-lasting inflations cannot always be tolerated by the patient. Catheter reperfusion techniques have made it possible to perform long inflations while keeping the patient perfused, and they also allow initial ischemic, hemodynamic stabilization as a "bridge" to immediate surgery. ${ }^{31,32}$ In selected patients, it was possible to obtain a satisfactory result with long-lasting inflations using the autoperfusion catheter. ${ }^{33,34}$ It should be noted, however, that it is not always possible to use autoperfusion catheters because vessels are small in caliber, tortuous, the lesions are angulated, or thrombus appears to play a significant role. The rather low efficacy of the "standard" management of acute coronary occlusion including redilation (even with longlasting inflations and a bigger balloon) thrombolytic treatment and emergency surgery has prompted the search for more effective treatment modalities. 
Table VIII. Incidence and related acute major complications of short-term occlusion after use of new interventional techniques

\begin{tabular}{|c|c|c|c|c|c|c|}
\hline & \multirow[b]{2}{*}{ Technique } & \multirow[b]{2}{*}{$\begin{array}{c}\text { No. of } \\
\text { patients }\end{array}$} & \multirow{2}{*}{$\begin{array}{c}\text { Short-term } \\
\text { occlusion } \\
\text { No. }(\%)\end{array}$} & \multicolumn{3}{|c|}{ Major complications } \\
\hline & & & & $\begin{array}{c}\text { Death } \\
\text { No. }(\%)\end{array}$ & $\begin{array}{c}A M I \\
\text { No. }(\%)\end{array}$ & $\begin{array}{c}E m C A B G \\
\text { No. }(\%)\end{array}$ \\
\hline \multirow{4}{*}{$\begin{array}{l}\text { Popma }{ }^{43 *} \\
\text { Lee }^{44 *} \\
\text { Aguirre }^{45} \dagger\end{array}$} & DCA & 934 & $43(4.3)$ & $2(0.2)$ & $17(1.8)$ & $25(2.7)$ \\
\hline & Excimer laser & 1893 & $123(6.5)$ & $9(0.4)$ & $54(2.9)$ & $63(3.3)$ \\
\hline & Rotational & & & & & \\
\hline & Coronary ablation & 907 & NR & $1(0.1)$ & $78(8.6)$ & $13(1.5)$ \\
\hline
\end{tabular}

$D C A$, Directional coronary atherectomy; other abbreviations as in Table I.

*Data pooled from Holmes et al. [Abstract]. Circulation 1991;84(suppl II):II-362; Bittl et al. [Abstract]. Circulation 1990;82(suppl III):III-670; and European Study Group [Abstract]. Circulation 1991;84(suppl II):II-362.

$\nmid$ Data pooled from Stertzer et al. J Am Coll Cardiol 1993;21:287-95; Bertrand et al. Am J Cardiol 1992;69:470-4; Teirstein et al. J Am Coll Cardiol 1991;18:1694-701; and Buchbinder et al. [Abstract]. J Am Coll Cardiol 1991;17(suppl A):31A.

Bail-out stenting for treatment of refractory acute coronary occlusion. Acute symptomatic occlusion refractory to repeat dilatation with or without adjunctive pharmacologic treatment is one of the most troublesome situations one may encounter during coronary angioplasty. A technique capable of restoring and maintaining antegrade flow, stabilizing the clinical condition, and obviating the need for emergency bypass surgery would be most welcome. Intracoronary stent implantation prevents vessel collapse and tacks back intimal and medial tears, sealing the thrombogenic subintimal space. Clinical experience with bail-out stent implantation was first reported by Sigwart et al. ${ }^{35}$ In a very limited number of patients, the self-expanding Wallstent was implanted, which resulted in an immediate restoration of adequate coronary flow, with normalization of the electrocardiogram (ECG) and relief of symptoms with no evidence of acute myocardial infarction. Since then, each of the current clinically available stents has been used for this purpose with encouraging results (Table VII). ${ }^{35-42} \mathrm{~A}$ high implantation success rate is reported, which is remarkable when one takes into account the technical difficulties that may be encountered in a bail-out situation. Disappearance of angiographic landmarks and spasm of the vessel segment may make stent delivery and correct positioning very laborious. Data from randomized studies proving the superiority of stenting over other techniques or devices are lacking. It appears that bail-out stenting reduces the need for emergency bypass surgery and decreases the incidence of acute myocardial infarction (Table VII). ${ }^{35-42}$ The results compare very favorably with those after abrupt closure following angioplasty without the use of bail-out stenting. This has prompted the recommendation that intracoronary stents should be available in all centers for bailout procedures.

A not totally resolved issue remains whether one should use a bail-out stent in situations associated with intracoronary thrombus formation, such as in patients with unstable angina or thrombotic abrupt occlusions. A case can be made for implanting a stent in association with the administration of thrombolytic treatment. It may be expected that the stent induces brisk coronary flow, whereas intense thrombolytic treatment dissolves remaining clot and anticoagulation prevents clot formation. Thrombolytic treatment has also been advocated if there is a high suspicion of clot formation within the stented area after bail-out stent implantation. The incidence of subacute stent thrombosis has been reported to vary between $9 \%$ and $18 \%$ (on average, 15\%) following bail-out stent implantation. 'To avoid stent thrombosis, an intensive and meticulous anticoagulation effort is necessary. This in turn exposes the patient to an increased risk of serious bleeding complications including intracranial bleeding in $0.5 \%$, gastrointestinal bleeding in $2.8 \%$, and groin bleeding in $7.5 \%$. Pseudoaneurysm at the puncture site occurs in $4.2 \%$ of patients.

There are no clear guidelines with respect to the decision to refer the patient for semielective bypass surgery after successful bail-out stent implantation. This decision should be based on a number of factors such as the clinical status of the patient after stenting (relief of angina, normalization of the ECG, or hemodynamic parameters), angiographic factors (acquired TIMI flow, presence or absence of intracoronary thrombus, complete or incomplete covering of the dissection, residual stenosis, territory at risk, presence or absence of collaterals), procedural factors (number and size of stents used), and the indication for bail-out stent implantation (suboptimal result versus threatened or frank vessel closure).

Acute coronary occlusion after new techniques. New interventional techniques such as directional atherectomy, the excimer laser, or rotational ablation have 
Table IX. Various indications for not performing percutaneous reintervention

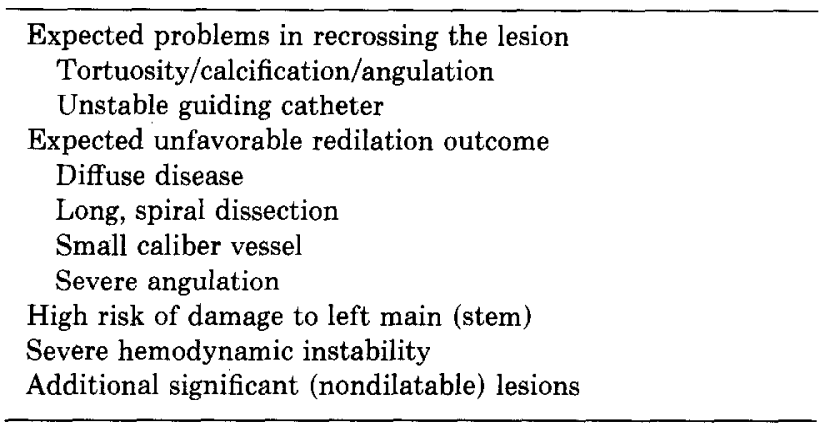

been developed to overcome some of the limitations of conventional balloon angioplasty. Unfortunately, these new techniques, although having the potential to be more effective in lesions where the balloon is limited, are associated with specific complications, in addition to the invariable occurrence of acute coronary occlusion and its related sequelae (Table VIII). ${ }^{43-45}$ Directional rotational ablation is associated with the no-flow phenomenon (up to $17 \%$ ) and the excimer laser is associated with coronary vessel perforation $(3.0 \%) .{ }^{46}$ In particular, bifurcation lesions and discrete noncalcific lesions have been shown to be associated with a higher likelihood of perforation with the excimer laser. It appears that the occurrence of acute closure and its related major complications is similar to that in balloon angioplasty, except for rotational coronary ablations, which appear to be associated with. a high myocardial infarction rate $(8.6 \%)$, albeit the majority of these instances were non-Q wave infarctions $(7.1 \%)$.

Current management of acute coronary occlusion. Crucial to the management of acute coronary occlusion is the necessity to keep the ischemic period as short as possible. Valuable time should not be wasted by cumbersome attempts to recross the lesion or to repeat unsuccessful dilatations, or to use techniques unfamiliar in the operator's catheterization laboratory. First, measures should be taken to relieve the pain and anxiety. One of the most important decisions one must make is whether the patient should be referred for emergency bypass surgery or whether a percutaneous technique should be selected (Fig. 1).

Various indications for not attempting a renewed percutaneous technique are listed in Table IX; these patients are referred for surgery. If one has opted for acute bypass surgery, measures should be taken to stabilize or eliminate myocardial ischemia before surgery. ${ }^{30}$ It has been shown that the results of surgery are better if the patients are not ischemic. ${ }^{28}$ If ischemia can not be reversed, precious time must not
Table $X$. Indications that preclude bail-out stent implantation

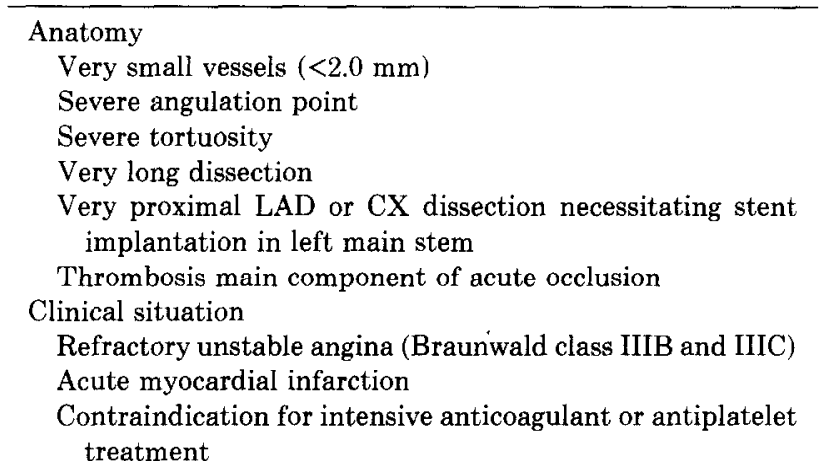

$L A D$, Left anterior descending coronary artery: $C X$, circumflex coronary artery.

be lost and the myocardium should be revascularized as soon as possible. If one has decided in favor of an attempt with a percutaneous technique such as is the case in the majority of patients, in particular if the guide wire is still across the lesion, one performs an immediate inflation (short or long-lasting) with the same or a bigger balloon or with the use of an autoperfusion balloon. If this fails and occlusive dissection appears the cause, one should now consider the implantation of a bail-out stent. Bail-out stent implantation is preferred above other new techniques (laser, directional coronary atherectomy [DCA]) because of its more general acceptance, wider availability, and proven efficacy. Again, it is important not to waste valuable time. Prompt stent placement is associated with a low incidence of both myocardial infarction and the need for emergency bypass surgery. ${ }^{47}$ However, stent implantation is precluded in the various situations listed in Table $\mathrm{X}$; in these situations it is probably wiser to refer the patient for emergency bypass surgery or, if thrombus formation is thought to play an important role, one may first attempt to reopen the vessel with adjunctive thrombolytic therapy. In hemodynamically unstable or life-threatening situations (left main artery occlusion or a very proximal, large left anterior descending artery), insertion of an intraaortic balloon pump or, if available, a percutaneous cardiopulmonary support device, should stabilize the patient and permit either a definite "work-up" of the acute occlusion or serve as a bridge until emergency surgery.

Conclusions. It is difficult to predict worse outcome during coronary intervention in an individual patient. The recently proposed AHA/ACC classification to predict success and complication rate appears outdated. A new updated classification should be devised, based on lesion-specification that will allow 


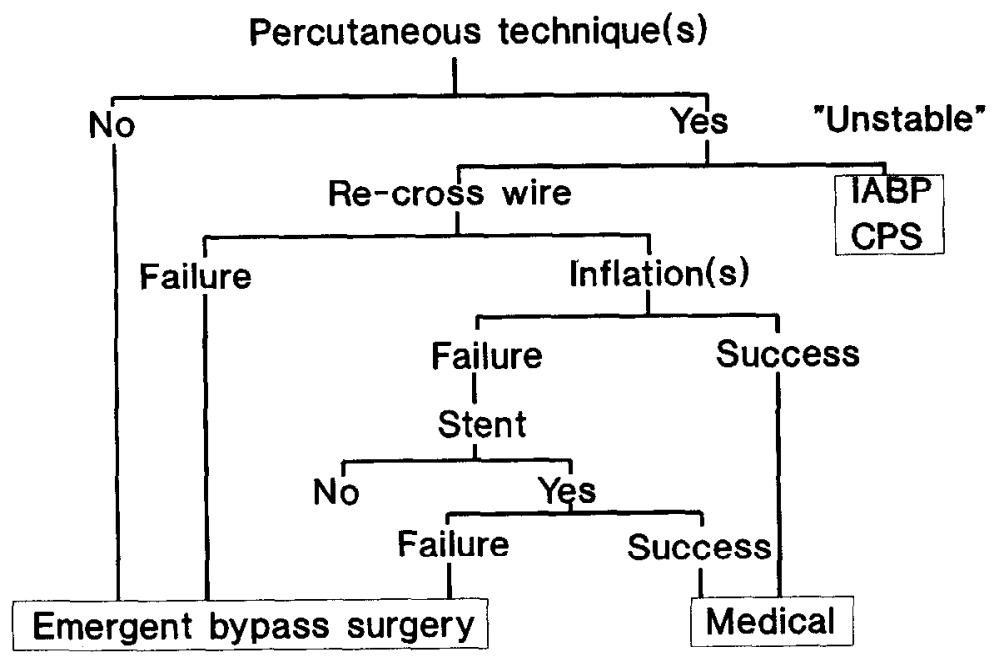

Fig. 1. Triage approach to the patient with acute coronary occlusion. $I A B P$, Intraaortic balloon pump; $C P S$, cardiopulmonary support.

classification of patients into high-, medium-, and low-risk groups. Ultravascular ultrasound will provide lesion-specific information that may either guide the use of specific devices or predict worse outcome. Newer techniques for specific lesions are expected to decrease acute complications. In case of acute occlusion, the use of angioscopy or intravascular ultrasound imaging will provide a better explanation of the direct underlying cause of the acute occlusion. Differentiation between dissection and thrombosis, and better delineation of the depth and extent of a dissection will increase our strategies to manage acute occlusion. Recoil or frank dissection will more readily be treated by intracoronary stenting techniques and we will be able to prevent or reverse acute occlusion in a substantial number of patients. The availability of more potent antiplatelet aggregation drugs, or newer anticoagulant drugs such as specific antithrombins, may provide options that may help us more effectively treat or prevent the occurrence of acute coronary occlusion. However, taking into account that the indications for coronary intervention are expected to expand, that these new cases will be associated with a higher likelihood of acute coronary occlusion, and that not all cases of acute occlusion can be reversed with percutaneous techniques, emergency surgery will still be needed. It is our opinion that a hospital with an interventional program should fulfil the following requirements: (1) guarantee the presence of operators familiar with long-lasting inflation and autoperfusion catheter techniques and (2) provide immediate access to a surgical back-up facility. In addition, such a facility should preferably have (1) operators skilled in bail-out stent techniques or
(2) availability of an intraaortic balloon pump or percutaneous cardiopulmonary support device.

\section{SUMMARY}

Acute coronary occlusion occurs in $4.3 \%$ to $8.3 \%$ of patients during coronary angioplasty. Its occurrence is difficult to predict in an individual patient. At high risk are patients with unstable angina, intracoronary thrombus, extreme age, long complex lesions, and diffuse disease. "Standard" management including redilation (prolonged perfusion) thrombolytic treatment and emergency bypass surgery is only successful in approximately $50 \%$ of the patients and is associated with a high mortality and myocardial infarction rate of $<6 \%$ and $30 \%$, respectively. Bail-out stent implantation appears to emerge as an effective alternative in suitable patients and might reduce mortality, the apparent progression to myocardial infarction, or might decrease the need for emergency bypass. New techniques including directional atherectomy, rotational ablation, or the excimer laser are associated with a similar frequency of acute occlusion. Immediate access to a surgical back-up facility remains necessary to treat refractory acute occlusions.

We thank Claudia Sprenger de Rover for expert manuscript preparation.

\section{REFERENCES}

1. Dorros G, Cowley MJ, Simpson J, Bentivoglio LG, Block PC, Baurassa M, Detre K, Gosselin AJ, Grüntzig AR, Kelsey SF, Kent KM, Mock MB, Mullin SM, Myler RK, Passamai ER, Stertzer SH, Williams DO. Percutaneous transluminal coronary angioplasty: report of complications from the National Heart, Lung, and Blood Institute PTCA Registry. Circulation 1983;67:723-30. 
2. Sinclair IN, McCabe CH, Sipperly ME, Baim DS. Predictors, therapeutic options and long-term outcome of abrupt reclosure. Am I Cardiol 1988;61:61G-6G.

3. Ellis SG, Roubin GS, King SB III, Douglas JS Jr, Weintraub WS, Thomas RG, Cox WR. Angiographic and clinical predictors of acute closure after native vessel coronary angioplasty. Circulation 1988;77:372-9.

4. Detre KM, Holmes DR Jr, Holubkov R, Cowley MJ, Baurassa MG, Foxon DP, Dorros GR, Bentivoglio LG, Kent KM, Myler RK, and coinvestigators of the National Heart, Lung, and Blood Institute's Percutaneous Transluminal Coronary Angioplasty Registry. Incidence and consequences of periprocedural occlusion of the 1985-1986 National Heart, Lung, and Blood Institute's Percutaneous Transluminal Coronary Angioplasty Registry. Circulation 1990;82:739-50.

5. de Feyter PJ, van den Brand M, Laarman GJ, van Domburg R, Serruys PW. Acute coronary artery occlusion during and after percutaneous transluminal coronary angioplasty. Frequency, prediction, clinical course, management and followup. Circulation 1991;83:927-36.

6. Lincoff AM, Popma JJ, Ellis SG, Hacker JA, Topol EJ. Abrupt vessel closure complicating coronary angioplasty: clinical, angiographic and therapeutic profile. J Am Coll Cardiol 1992; 19:926-35.

7. Myler RK, Shaw RE, Stertzer SH, Hecht HS, Ryan C, Rosenblum J, Cumberland DC, Murphy MC, Hansell HN, Hidalgo B. Lesion morphology and coronary angioplasty: current experience and analysis. J Am Coll Cardiol 1992;19:1641-52.

8. Holmes DR Jr, Holubkov R, Vlietstra RF, Kelsey SF, Reeder GS, Dorros G, Williams DO, Cowley MJ, Faxon DP, Kent KM, Bentivoglio LG, Detre $K$, and the coinvestigators of the National Heart, Lung, and Blood Institute Percutaneous Transluminal Coronary Angioplasty Registry. Comparison of complications during percutaneous transluminal coronary angioplasty from 1977 to 1981 and from 1985 to 1986: the $\mathrm{Na}$ tional Heart, Lung, and Blood Institute Percutaneous Transluminal Coronary Angioplasty Registry. J Am Coll Cardiol 1988;12:1149-55.

9. Waller BF. Crackers, breakers, stretchers, drillers, scrapers, shavers, burners, welders and melters - the future treatment of atherosclerotic coronary artery disease? A clinical morphologic assessment. J Am Coll Cardiol 1989;13:969-87.

10. Block PC, Myler RK, Stertzer S, Fallon JT. Morphology after transluminal angioplasty in human beings. $\mathbf{N}$ Engl $\mathbf{J}$ Med 1981;305:382-5.

11. Fischell TA, Derby G, Tse TM, Stadius ML. Coronary artery vasoconstriction routinely occurs after percutaneous transluminal coronary angioplasty. A quantitative arteriographic analysis. Circulation 1988;78:1323-34.

12. Rensing BJ, Hermans WRM, Beatt KJ, Laarman GJ, Suryapranata $H$, van den Brand $M$, de Feyter PJ, Serruys PW. Quantitative angiographic assessment of elastic recoil after percutaneous transluminal coronary angioplasty. Am J Cardiol 1990;66:1039-44.

13. Ellis SG, Vandormael MG, Cowley MJ, DiSciascio G, Deligonul U, Topol EJ, Bulle TM, and the Multivessel Angioplasty Prognosis Study Group. Coronary morphologic and clinical determinant of procedural outcome with angioplasty for multivessel coronary disease. Implications for patient selection. Circulation 1990;82:1193-202.

14. Hermans WRM, Foley DP, Rensing BJ, Rutsch W, Heyndrickx GR, Danchin N, Mast G, Hanet C, Rablanche JM, Rafflenbeul W, Uebis R, Balcon R, de Feyter PJ, Serruys PW, on behalf of the Carport and Mercator Study Group. Usefulness of quantitative and qualitative angiographic lesion morphology, and clinical characteristics in predicting major adverse cardiac events during and after native coronary balloon angioplasty. Am J Cardiol 1993;72:14-20.

15. Kern MJ, Deligonul U, Galan K, Zelman R, Gabliani G, Bell ST, Bodet J, Naunheim K, Vandormael M. Percutaneous transluminal angioplasty in octogenarians. Am J Cardiol 1988; 61:457-8.
16. Barnathan ES, Schwartz SJ, Taylor L, Laskey WK, Kleaveland P, Kussmaul WG, Hirshfeld JW Jr. Aspirin and dipyridamole in the prevention of acute coronary thrombosis complicating coronary angioplasty. Circulation 1987;76:125-34.

17. Ellis SG, Roubin GS, King SB III, Douglas JS Jr, Shaw RE, Stertzer SH, Myler RK. In-hospital cardiac mortality after acute coronary angioplasty: analysis of risk factors from 8,207 procedures. J Am Coll Cardiol 1988;11:211-6.

18. Hollman J, Gruentzig AR, Douglas JS, King SB, Ischinger T, Meier B. Acute occlusion after percutaneous transluminal coronary angioplasty-a new approach. Circulation 1983; 68:725-32.

19. Marquis JF, Schwartz L, Aldridge H, Majid P, Henderson M, Matahinsky E. Acute coronary artery occlusion during percutaneous transluminal coronary angioplasty treated by redilation of the occluded segment. J Am Coll Cardiol 1984;4:126871.

20. Gulba DC, Daniel WG, Simon R, Jost S, Barthels M, Amende I, RafflenbeuI W, Lichtlen PR. Role of thrombolysis and thrombin in patients with acute coronary occlusion during percutaneous transluminal coronary angioplasty. J Am Coll Cardiol 1990;16:563-8.

21. Schieman G, Cohen BM, Kozina J, Erickson JS, Podolin RA, Peterson KL, Ross J Jr, Buchbinder M. Intracoronary urokinase for intracoronary thrombus accumulation complicating percutaneous transluminal coronary angioplasty in acute ischemic syndromes. Circulation 1990;82:2052-60.

22. Verna E, Repetto S, Boscarini M, Onofri M, Quing LG, Binaghi $\mathrm{G}$. Management of complicated coronary angioplasty by intracoronary urokinase and immediate reangioplasty. Cathet Cardiovasc Diagn 1990;19:116-22.

23. Vaitkus PT, Herrmann HC, Laskey WK. Management and immediate outcome of patients with intracoronary thrombus during percutaneous transluminal coronary angioplasty. AM Heart J 1992;124:1-8.

24. Cowley MJ, Dorros G, Kelsey SF, Van Raden M, Detre KM. Emergency coronary bypass surgery after coronary angioplasty: The National Heart, Lung, and Blood Institute's Percutaneous Transluminal Coronary Angioplasty Registry experience. Am J Cardiol 1984;53:22C-6C.

25. Golding LAR, Loop FD, Hollman JL, Franco I, Borsh J, Stewart RW, Lytle BW. Early results of emergency surgery after coronary angioplasty. Circulation 1986;74:(suppl III)III26-9.

26. Killen DA, Hamaker WR, Reed WA. Coronary artery bypass following percutaneous transluminal coronary angioplasty. Ann Thorac Surg 1985;40:133-8.

27. Reul GJ, Cooley DA, Hallman GL, Duncan JM, Livesay JJ, Frazier OH, Ott DA, Angelini P, Massumi A, Mathur VS. Coronary artery bypass for unsuccessful percutaneous transluminal coronary angioplasty. J Thorac Cardiovasc Surg 1984;88:685-94.

28. Talley JD, Weintraub WS, Roubin GS, Douglas JS, Anderson V, Jones EL, Morris DC, Liberman HA, Craver JM, Guyton RA, King SB. Failed elective percutaneous transluminal coronary angioplasty requiring coronary artery bypass surgery. In-hospital and late clinical outcome at 5 years. Circulation 1990;82:1203-13.

29. Greene MA. Emergency aortocoronary bypass after failed angioplasty. Ann Thorac Surg 1991;51:194-9.

30. Weintrauh WS, Cohen CI, Curling PE, Jnnes FI, Craver .JM, Guyton R, King SB III, Douglas JS. Results of coronary surgery after failed elective coronary angioplasty in patients with prior coronary surgery. J Am Coll Cardiol 1990;16:1341-7.

31. Ferguson TB, Hinohara T, Simpson J, Stack RS, Wechsler AS Catheter reperfusion to allow optimal coronary bypass grafting following failed transluminal coronary angioplasty. Ann Thorac Surg 1986;42:399-405.

32. Sundram P, Harvey JR, Johnson RG, Schwartz MJ, Baim DS. Benefit of the perfusion catheter for emergency coronary artery grafting after failed PTCA. Am J Cardiol 1989;63: $282-5$. 
33. van Lierde JM, Glazier JJ, Stammen FJ, Vrolix MC, Sionis D, De Geest H, Piessens JH. Use of an autoperfusion catheter in the treatment of acute refractory vessel closure after coronary balloon angioplasty: immediate and six-month follow-up results. Br Heart J 1992;68:51-4.

34. Jackman JD, Zidar JP, Tcheng JE, Overman AB, Phillips HR, Stack RS. Outcome after prolonged balloon inflations of $>20$ minutes for initially unsuccessful PTCA. Am J Cardiol 1992; 69:1417-21.

35. Sigwart U, Urban PH, Golf S, Kaufmann U, Imbert C, Fischer A, Kappenberger L. Emergency stenting for acute occlusion after coronary balloon angioplasty. Circulation 1988;78:1121-7.

36. de Feyter PJ, DE Scheerder IK, van den Brand M, Laarman GJ, Suryapranata H, Serruys PW. Emergency stenting for refractory acute coronary artery occlusion during coronary angioplasty. Am J Cardiol 1990;66:1147-50.

37. Goy JJ, Sigwart U, Vogt P, Stauffer JC, Kappenberger L. Long-term clinical and angiographic follow-up of patients treated with the self-expanding coronary stent for acute occlusion during balloon angioplasty of the right coronary artery. J Am Coll Cardiol 1992;19:1593-6.

38. Haude M, Erbel R, Straub U, Dietz U, Schatz R, Meyer J. Results of intracoronary stents for management of coronary dissection after balloon angioplasty. Am J Cardiol 1991;67:691-6.

39. Herrmann HC, Buchbinder M, Clemen MW, Fischman D, Goldberg S, Leon MB, Schatz RA, Tierstein P, Walker CM, Hirshfeld JW Jr. Emergent use of balloon-expandable coronary artery stenting for failed PTCA. Circulation 1992; $86: 812-9$.
40. Reifart N, Langer A, Storger H, Schwarz F, Preusler W, Hoffmann P. Strecker stent as a bailout device following percutaneous transluminal coronary angioplasty. J Intervent Cardiol 1992;5:79-83.

41. Roubin GS, Cannon AD, Agrawal SK, Macander PJ, Dean LS, Baxley WA, Breland J. Intracoronary stenting for acute and threatened closure complicating percutaneous transluminal coronary angioplasty. Circulation 1992; 85:916-27.

42. Vrolix M, van der Kricken T, Piessens J. Wiktor stent for acutc and threatened closure after coronary angioplasty: an update of the European Registry [Abstract]. Ciruclation 1992;86:987A.

43. Popma JJ, Topol EJ, Hinohara T, Pinkerton CA, Baim DS, King SB, Holmes DR, Whitlow PL, Kereiakes DJ, Hartzler GD, Kent KK, Ellis SG, Simpson JB. Abrupt vessel closure after directional coronary atherectomy. J Am Coll Cardiol 1992;19:1372-9

44. Lee G, Mason DT. Excimer coronary laser angioplasty: it's time for a critical evaluation. Am J Cardiol 1991;69:1640-3.

45. Aguirre FV, Bach R, Donohue TJ, Caracciolo E, Kern MJ. Rotational coronary ablation: more grist for the interventional mill? J Am Coll Cardiol 1993;21:296-7.

46. Bitl JA, Ryan TJ, Keaney JF, Tscheng JE, Ellis SG, Isner JM, Sanborn TA. Coronary artery perforation during excimer laser coronary angioplasty. J Am Coll Cardiol 1993;21:1158-65.

47. Lincoff AM, Topol EJ, Chapekis A'T, George BS, Candela RJ, Muller DWM, Zimmerman CA, Ellis SG. Intracoronary stenting compared with conventional therapy for abrupt vessel closure complicating coronary angioplasty: a matched-case control study. J Am Coll Cardiol 1993;21:866-75.

\title{
Thrombolytic therapy in infants and children
}

\author{
Shyam Sunder Kothari, DM, Sudhir Varma, DM, and Harbans Singh Wasir, DM \\ New Delhi, India
}

Thrombolytic therapy has been extensively used in adults. Several recent reviews have summarized the pharmacologic and clinical aspects of various thrombolytic agents. ${ }^{1-3}$ This therapy is also being increasingly used in neonates, infants, and children to treat various cardiac and other disorders. However, there appears to be an insufficient appreciation of the indications, efficacy, and safety of these agents in the pediatric population. In this article we review the published literature on the use of thrombolytic ther-

\footnotetext{
From the Department of Cardiology, Cardiothoracic Centre, All India Institute of Medical Sciences.

Received for publication April 19, 1993; accepted August 2, 1993.

Reprint requests: S. S. Kothari, DM, Department of Cardiology, C.T. Centre, All India Institute of Medical Sciences, New Delhi-110 029, India.

AM HEART J 1994;127:651-7.

Copyright 1994 by Mosby-Year Book, Inc.

$0002-8703 / 94 / \$ 3.00+0 \quad \mathbf{4} / \mathbf{1} / \mathbf{5 1 9 5 3}$
}

apy in neonates, infants, and children, and other related issues. A wider appreciation of the contemporary experience would help in optimizing the utilization of thrombolytic therapy in the pediatric population. Streptokinase (SK), urokinase (UK), and recombinant tissue plasminogen activator (rTPA) have been used to treat the disorders discussed below.

\section{CLINICAL APPLICATIONS}

Arterial thrombosis after cardiac catheterization. Arterial thrombosis after retrograde arterial catheterization occurs in $0.8 \%$ to $3.4 \%$ of patients despite systemic heparinization. ${ }^{4,5}$ It is more common in patients weighing less than $10 \mathrm{~kg}$ and in whom balloon dilatation procedures are done through the arterial route. Consequently, the incidence of this complication seems to be rising. Surgical thrombectomies in young patients do not produce optimal results ${ }^{6}$ and might extend the vascular injury. On the other hand, 